For citation: Ribeiro M. I., Fernandes A. J., Cabo P. S. \& Diniz F. J. (2019). Trends in Honey Purchase and Consumption in Trás-os-Montes Region, Portugal. Ekonomika Regiona [Economy of Region], 15(3), 822-833

doi 10.17059/2019-3-15

UDC: 332.1

JEL Codes: L66, Q13, R10

\author{
M. I. Ribeiro ${ }^{\mathrm{a}, \mathrm{b})}$, A. J. Fernandes ${ }^{\mathrm{a}, \mathrm{b})}$, P. S. Cabo ${ }^{\mathrm{a}, \mathrm{b})}$, F. J. Diniz ${ }^{\mathrm{c}, \mathrm{d})}$ \\ a) Bragança Polytechnic Institute (Bragança, Portugal) \\ b) Mountain Research Center(Bragança, Portugal) \\ c) University of Trás-os-Montes e Alto Douro (Vila Real, Portugal; e-mail: fdiniz@utad.pt) \\ d) Centre for Transdisciplinary Development Studies (Vila Real, Portugal)
}

\title{
TRENDS IN HONEY PURCHASE AND CONSUMPTION IN TRÁS-OS-MONTES REGION, PORTUGAL
}

Honey is considered the only food of animal origin that can be consumed without being processed. The literature presents several reasons why people consume honey, namely, it being a natural and healthy product known for its dietary, nutritional and medicinal characteristics. Moreover, other reasons for honey's purchase include the product quality; the region of origin; the information available on the product's label, the brand's reputation; and the variety, texture, taste, aroma, appearance, packaging and price of honey. Thus, we intend to identify determinant factors on which consumers base their purchasing decision. Therefore, we developed a cross-sectional study based on a non-probabilistic sample of 474 individuals, 399 of whom were honey consumers. We collected the data in the period from March to May 2016 using a questionnaire [1], which we applied directly to consumers in the city of Bragança. Later, we analysed the data with SPSS 23.0 software. The data analysis included a univariate descriptive analysis and a multivariate analysis that involved assessment of a binary logistic regression in order to identify the determinant factors for purchasing and consuming honey. The statistically significant parameters included taste, colour, origin, and certification label, at a significance level of $1 \%$. These characteristics explained $68.9 \%$ of the consumer's decision to purchase honey. It is noteworthy that non-consumers considered the certification label important (when purchasing the product to offer to someone), while in the process of decision-making honey consumers valued taste, colour and country of origin.

Keywords: Consumers, Honey, Trends, Determinant factors, Purchase

\section{Introduction}

Apiculture is regarded as a strategic activity for an integrated and economically sustainable use of countryside. Indeed, beekeeping is a crucial activity for the future of rural world, especially, for agriculture, as a source of income and employment. Moreover, beekeeping plays an important role in the pollination of native species and agricultural crops. Furthermore, the current healthy life style trend, which includes consumption of natural products, influenced the demand for beehive products, as their consumption is beneficial for human health. As it happens, honey is a natural product, not subject to any transformation process, which has in its composition several elements responsible for its medicinal, therapeutic, dietetic and nutritional properties $[2,3]$. Used mainly as a sweetener, this product has al-

\footnotetext{
${ }^{1}$ (c) Ribeiro M. I., Fernandes A. J., Cabo P. S., Diniz F. J. Text. 2019. Work presented at the International Conference on Economics, Antalaya, Turkey, 1 to 3 November 2018.
}

ways been appreciated for its therapeutic properties, due to its digestive, analgesic, anti-inflammatory, antimicrobial and antiseptic characteristics, among others [4].

In agro-food products, consumers base their first impression of the product on its appearance. Such characteristics as colour, shape or size may also appeal to consumers. Additionally, consumers feel stimulated by the four variables of marketing-mix, namely product, price, promotion and place. The literature highlights several reasons why people consume honey, namely, it being a natural and healthy product known for its dietary, nutritional and medicinal characteristics. Moreover, other reasons for honey's purchase include the product quality; the region of production; the information available on the product's label, the brand's reputation; and the variety, texture, taste, aroma, appearance, packaging and price of honey $[1,5]$.

This study aims to outline the profile of honey consumer in Bragança, describe his purchasing and consumption habits and identify the attrib- 
utes of honey on which consumers base their purchasing decision.

To achieve these objectives, we developed a quantitative, observational, cross-sectional and analytical study, based on an accidental sample of 474 individuals. We collected the data through a questionnaire [1] that we applied directly to the inhabitants of Bragança in the spring of 2016. The statistical analysis involved calculation of the absolute and relative frequencies since the variables were qualitative. For comparing the profiles of honey consumers and non-consumers, in case of qualitative variables, we used the Pearson's Chisquare test. In case of quantitative variables, we applied the Mann-Whitney test. Finally, we assessed a binary logistic regression to identify the determinants of honey consumption.

\section{Theoretical Framework}

Beekeeping is an activity that has positive social, economic and environmental impacts $[6,7]$. Nowadays, it plays a key role in the sustainability of the economy of rural territories with small density. Persisting as a viable economic alternative for the rural population, beekeeping, subsequently, positively contributes to fight against human desertification in rural areas. Honey consumption has increased worldwide, due to recognition of its medicinal, therapeutic and nutritional properties.

Due to its constituents, honey is known for its pharmacological activity, namely, antidiabetic (honey is an excellent substitute for sugar, especially for patients with diabetes) [8, 9]; antitumor [9]; antibacterial and antimicrobial [9, 10-16]; antifungal $[11,12]$; diuretic and metabolic (honey increases the metabolism of alcohol in the blood). Furthermore, it has the following pharmacological characteristic; immunomodulatory [12, 17]; antioxidant $[9,14,18-20]$; anti-inflammatory and dermatological (honey not only inhibits bacteria, but provides a physical barrier impermeable between the wound and the bacteria, favouring the healing of wounds, burns and minimizing the effects of various skin diseases) [15, 16, 19, 21].

In comparison to topical agents, such as silver hydrogel or silver sulfadiazine, honey is more effective in eliminating microbial contamination, reducing wound area and improving epithelization. In addition, it stimulates the growth of wound tissues by accelerating the healing process and initiates anti-inflammatory activity, promptly reducing pain, edema and exudate production [15]. Honey also has beneficial properties in otolaryngology, namely, in the prevention and treatment of oral infections, respiratory tract infections, rhinosinusal disease and otitis media. Honey is also considered effective in the (additional) treatment of mucositis, infantile cough, persistent post-infectious cough and after tonsillectomy [22]. In cosmetics, honey is usually used in the production of creams, lotions and shampoos. The honey-based preparations have a softening, conditioning and moisturizing effect on the skin and hair [23].

The world honey market is constantly changing and adapting to current consumption trends [2], reflecting the dynamics of consumer behaviour. Nowadays, individuals are more rational and increasingly demanding in relation to the products consumed [6]. Embracing a healthy lifestyle based on the consumption of unprocessed and natural foods, as well as treating the diseases using natural products, contributed to the increase in the consumption of honey. Indeed, honey is a product whose authenticity and innate properties are recognized by consumers [2, 24], considering it is the only food of animal origin that can be consumed without any previous transformation $[2,25]$.

The literature refers several reasons influencing the consumption of honey, namely, the fact of being a natural and healthy product; its dietetic, nutritional and medicinal characteristics; the product quality; the region of origin; the information available on the product label, the reputation of the brand; as well as, the variety, and sensory characteristics such as texture, taste, aroma, appearance, plus, packaging and price [1, 26, 27-33].

Europe is the world's second largest honey producer. In spite of this, European honey market demonstrates a structural imbalance between demand and domestic production, as around $40 \%$ of Europe's consumption needs are satisfied by extra-European sources. In fact, honey imports have grown significantly since 2011. It happened because of a decline in the significance of the European beekeeping sector, changing climatic conditions (drought), bees' diseases, and the intensive use of chemicals, which are lethal to bees, in agriculture. Germany is the main European importer and consumer of honey, representing, structurally, around $26 \%$ and $23 \%$ of the volume of European honey imports and consumption, respectively [34, 35].

Portugal has a favourable climate for the practice of beekeeping. Nevertheless, historically, apiculture has been considered a complementary activity to agriculture, or a hobby. Currently, despite a decreased total of beekeepers, the size of honey bee farms and the number of full-time commercial beekeepers increased (from $4 \%$ in 2013 to $10 \%$ in 2015), consequently reinforcing honey's production capacity [36]. Portuguese honey production is increasing significantly, by around 
$158 \%$ from 2000 to 2015 [35, 36], producing 11521 tonnes of honey in 2015 [36]. Similarly, the purchase of honey for eating greatly increased by nearly $71 \%$ from 2000 to 2013 . In 2013 , the consumption of honey per capita was, approximately, $0.91 \mathrm{~kg}$ per year [35]. The current valorisation of the international market, the sector's organization, and the dynamics and investment into qualitative production of bee products are the main reasons for the good performance of domestic beekeeping sector [36].

\section{Methodology}

In the study, we focus on outlining the profile of the honey consumer in the city of Bragança, describing his purchasing and consumption habits and identifying the attributes on which consumers base the purchasing decision. Thus, we conducted a cross-sectional, observational, quantitative and analytical study out. We chose a cross-sectional method, as we collected the data in the short period, providing a «picture» of the variables studied at a given moment. On the hand, the study can be classified as observational, as it belongs to the social sciences and aims to outline the profile of the honey consumer and describe his purchasing and consumption habits in Bragança, a city located in Trás-os-Montes region in the northeast of Portugal. On the other hand, it can be classified as quantitative, as it allows representing the obtained knowledge in the form of graphs, diagrams and calculations. Finally, this study is analytical because, beyond the use of descriptive statistics, it allows studying relations between variables [37].

We collected the data in the period from March to May 2016. We used a questionnaire [1] applying it directly to consumers over the age of 18 in commercial and public places in the city of Bragança. The respondent consumers had decision-making power and/or were household food buyers. The questionnaire had three parts. The first part included socio-economic questions, namely, gender, age, occupation, level of education, monthly household income, number of household members, and place of residence. The second part contained questions on the habits of honey consumption, including the time of year and frequency of honey consumption, preferred country of origin (domestic versus foreign origin) and ways of utilizing honey. Finally, the third part had questions concerning the buying habits, namely, place, purchase-determining factors and choice of honey's packaging (size, type, material and label). The questionnaire was anonymous and brief (no more than ten minutes). Prior to the questionnaire's ap- plication, we asked permission from the management of commercial areas.

For conducting the study, we collected a representative sample, composed of 474 individuals, which constitutes more than $1 \%$ of the studied population. In fact, in 2011, the population of the county of Bragança was of 35341 inhabitants [38]. The sample included individuals aged between 18 and 99 years old. The mean was 35.4 years old ( \pm 14.7). As Table 1 demonstrates, the majority of respondents was between 25 and 64 years old (62.5\%), male (57.1\%), employed (47.4\%), had a higher education degree (41.7\%), lived in households of $3(20.7 \%)$ and 4 people (38.0\%), with a monthly household income up to 999 euros (51.5\%) in urban settings (55.9\%).

Afterward, we analysed the data using SPSS software (Statistical Package for Social Sciences) 23.0. Initially, we conducted a descriptive study involving the calculation of descriptive statistics, namely, absolute and relative frequencies for qualitative variables, measures of central tendency, and dispersion for quantitative variables $[39,40]$. Next, we conducted an analytical study

Table 1

Sample description

\begin{tabular}{|c|c|c|c|}
\hline \multirow{2}{*}{ Variable } & \multirow{2}{*}{ Categories } & \multicolumn{2}{|c|}{ Frequencies } \\
\hline & & $n$ & $\%$ \\
\hline \multirow{2}{*}{$\begin{array}{l}\text { Gender } \\
(N=473)\end{array}$} & Male & 270 & 57.1 \\
\hline & Female & 203 & 42.9 \\
\hline \multirow{3}{*}{$\begin{array}{l}\text { Age class } \\
(N=469)\end{array}$} & From 18 to 24 years & 155 & 33.0 \\
\hline & From 25 to 64 years & 293 & 62.5 \\
\hline & $\geq 65$ years & 21 & 4.5 \\
\hline \multirow{4}{*}{$\begin{array}{l}\text { Professional } \\
\text { status } \\
(N=441)\end{array}$} & Employed & 209 & 47.4 \\
\hline & Student & 148 & 33.6 \\
\hline & Unemployed & 65 & 14.7 \\
\hline & Retired & 19 & 4.3 \\
\hline \multirow{5}{*}{$\begin{array}{l}\text { Level of } \\
\text { education } \\
(N=470)\end{array}$} & 1st cycle & 27 & 5.7 \\
\hline & 2nd cycle & 27 & 5.7 \\
\hline & 3th circle & 52 & 11.1 \\
\hline & Secondary & 168 & 35.7 \\
\hline & Higher & 196 & 41.7 \\
\hline \multirow{5}{*}{$\begin{array}{l}\text { Monthly } \\
\text { household } \\
\text { income } \\
(N=468)\end{array}$} & $<599$ euros & 105 & 22.4 \\
\hline & 600 to 999 euros & 136 & 29.1 \\
\hline & 1000 to 1499 euros & 121 & 25.9 \\
\hline & 100 to 1999 euros & 58 & 12.4 \\
\hline & $\geq 2000$ euros & 48 & 10.2 \\
\hline \multirow{5}{*}{$\begin{array}{l}\text { Household } \\
\text { size } \\
(N=474)\end{array}$} & 1 person & 54 & 11.4 \\
\hline & 2 people & 92 & 19.4 \\
\hline & 3 people & 98 & 20.7 \\
\hline & 4 people & 180 & 38.0 \\
\hline & $\geq 5$ people & 50 & 10.5 \\
\hline \multirow{2}{*}{$\begin{array}{l}\text { Residence } \\
(N=472)\end{array}$} & Rural & 208 & 44.1 \\
\hline & Urban & 264 & 55.9 \\
\hline
\end{tabular}


in order to compare the proportions of the studied socio-economic characteristics, namely, gender, age, professional status, level of education, monthly household income, size of household and place of residence, that were statistically different, considering whether the respondent was a honey consumer or not. For these qualitative variables, we used the Pearson's Chi-square [39]. In order to compare the age (quantitative variable), taking into account the same factor, we used the Mann-Whitney test $[39,40]$. Then we tested the conditions of application of the parametric tests (the normality of the data) using the KolmogorovSmirnov test with the Lilliefors correction $(n>30)$ and the homogeneity of variances using the Levene's test. We found out that both values were violated ( $p$-value $<0.05$ ). For the aforementioned reasons, we also used the Mann-Whitney test to compare the price of honey taking into account the case of the respondent being simultaneously consumer and producer of honey.

For conducting the analytical study, we used a confidence level $(1-\alpha)$ of $95 \%$, corresponding to a level of significance $(\alpha)$ of $5 \%$. The decision rule is to reject the null hypothesis $(\mathrm{H} 0)$ when the p-value is less than or equal to the significance level, that is, when $p$-value $\leq \alpha$ [39]. The probability of significance or $p$-value is the lowest level of $\alpha$ for which it is possible to reject HO [39]. The Pearson's Chisquare test allows testing the null hypothesis that the proportion of a respondent's given attribute is the same, regardless of whether they are a honey consumer or not (H0: $\theta_{\text {Yes }}=\theta_{\mathrm{No}}$ vs H1: $\left.\theta_{\text {Yes }} \neq \theta_{\text {No }}\right)$ where $\theta$ is the proportion. The Mann-Whitney test allows testing the null hypothesis (the medians of the variable age are equal) against the alternative hypothesis (the age of honey consumer differs from the age of non-consumers). The formula is H0: $\eta_{\text {Yes }}=\eta_{\mathrm{No}}$ vs H1: $\eta_{\text {Yes }} \neq \eta_{\mathrm{No}}$, where $\eta$ is the median. The Mann-Whitney test allows comparing honey prices by taking into account whether or not honey consumer is also producer.

Finally, we used the multivariate analysis, namely, the assessment of a binary logistic regression, in order to identify the determinants of honey consumption at a significance level of $1 \%$. In the assessment of the logistic regression model, we used the stepwise method for choosing the factors. The probability of honey consumption $(p)$ is defined by the logit transformation as function of explanatory factors.

$$
p\left(Y_{i}=0\right)=\frac{1}{1+e^{-X \beta}},
$$

where $Y, X$ and $\beta$ are, respectively, $Y$ is a binary dependent variable, which assumes the value of 0 , in case of a honey consumer, and the value of 1 , in case of non-consumer; $X$ is the column vector of dimension $p+1$, where $p$ is the number of explanatory variables; $\beta$ is an unknown parameter vector to be estimated.

The likelihood ratio $(L R)$ was used for assessing the model's overall validity.

$$
R V=2 L L_{\text {final }}-2 L L_{\text {original }} \sim \chi_{(k-1)}^{2} .
$$

To verify the individual significance of the parameters, we tested the null hypothesis $\mathrm{H} 0: \beta_{j}=0$ against the alternative hypothesis $\mathrm{H} 1: \beta_{j} \neq 0$. We evaluated the goodness of fit of the logistic regression model using the Nagelkerke's $R$ squared $\left(R^{2}\right.$ Nagelkerke), which reveals the power of the model's explanation (i.e., the proportion of variation explained in the model of logistic regression), expressed by the formula (3):

where:

$$
R_{\text {Nagel ker ke }}^{2}=\frac{R_{\text {Cox\&Snell }}^{2}}{1-\left(2 L L_{\text {original }}\right) 2 / n},
$$

$$
R_{\text {Cox\&Snell }}^{2}=1-\left[\frac{2 L L_{\text {original }}}{2 L L_{\text {final }}}\right]^{2 / n} \text {. }
$$

\section{Results}

The distribution of respondents according to production and consumption of honey can be observed in Figure 1. It shows that $84.2 \%$ of the respondents were honey consumers (399 individuals) and only $8.9 \%$ were honey producers.

Honey consumers were aged between 18 and 99 years old. The mean was 35.6 years old $( \pm 15.1)$. As it can be seen in Table 2, the majority of consumers was between 25 and 64 years old (61.2\%), female (58.1\%), employed (45.6\%), had higher education (40.6\%), lived in households of 3 (21.6\%) and 4 people (36.3\%) with a monthly household income up to 999 euros (50.5 \%), in urban settings (56.1\%). A study conducted in Romania revealed a similar profile of honey consumers [41].

The comparison of the profiles of honey consumers and non-consumers, using the Pearson's Chi-square test, have shown that there are statistically significant differences in two characteristics, namely, in the professional status ( $p$-value $<0.01)$ and in the household monthly income ( $p$-value $<0.05$ ) (Table 2). Thus, it can be stated, with a confidence level of $99 \%$, that the proportion of honey consumers is higher when consumers are employed. On the contrary, the proportion of non-consumers is statistically higher in case of unemployed persons.

The results presented in Table 2 show, with a degree of confidence of $95 \%$, that the respond- 
Are you a honey consumer? $(\mathrm{N}=474)$

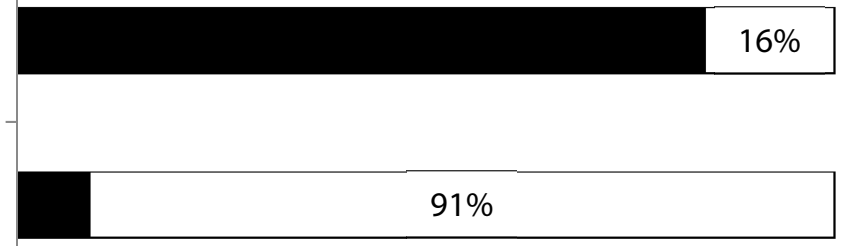

Are you a honey producer? $(\mathrm{N}=473)$

- Yes $\quad \square$ No

Fig. 1. Distribution of respondents for production and consumption of honey

Table 2 ents consuming more honey obtain a monthly

Socio-economic profile of honey consumer

\begin{tabular}{|c|c|c|c|c|}
\hline \multirow{2}{*}{ Variable } & \multirow{2}{*}{ Categories } & \multicolumn{2}{|c|}{$\begin{array}{c}\text { Honey consumer } \\
(\%)\end{array}$} & \multirow{2}{*}{$P$-value } \\
\hline & & $\begin{array}{c}\text { No } \\
(n=75)\end{array}$ & $\begin{array}{c}\text { Yes } \\
(n=399)\end{array}$ & \\
\hline \multirow{3}{*}{ Gender } & Male & 49.3 & 41.6 & \multirow{3}{*}{0.221} \\
\hline & Female & 50.7 & 58.1 & \\
\hline & Missing & 0.0 & 0.3 & \\
\hline \multirow{4}{*}{ Age class } & 18 to 24 years & 29.3 & 33.3 & \multirow{4}{*}{0.576} \\
\hline & 25 to 64 years & 65.3 & 61.2 & \\
\hline & $\geq 65$ years & 2.7 & 4.8 & \\
\hline & Missing & 2.7 & 0.8 & \\
\hline \multirow{5}{*}{$\begin{array}{l}\text { Profes- } \\
\text { sional } \\
\text { status }\end{array}$} & Employed & 36.0 & 45.6 & \multirow{5}{*}{$0.002^{*}$} \\
\hline & Student & 28.0 & 31.8 & \\
\hline & Unemployed & 28.0 & 11.0 & \\
\hline & Retired & 2.7 & 4.3 & \\
\hline & Missing & 5.3 & 7.3 & \\
\hline \multirow{6}{*}{$\begin{array}{l}\text { Level of } \\
\text { education }\end{array}$} & 1st cycle & 8.0 & 5.3 & \multirow{6}{*}{0.691} \\
\hline & 2nd cycle & 6.7 & 5.5 & \\
\hline & 3 th circle & 10.7 & 11.0 & \\
\hline & Secondary & 29.3 & 36.6 & \\
\hline & Higher & 45.3 & 40.6 & \\
\hline & Missing & 0.0 & 1.0 & \\
\hline \multirow{6}{*}{$\begin{array}{l}\text { Monthly } \\
\text { house- } \\
\text { hold } \\
\text { income }\end{array}$} & $<599$ euros & 21.3 & 22.3 & \multirow{6}{*}{$0.044^{* *}$} \\
\hline & $\begin{array}{l}600 \text { to } 999 \\
\text { euros }\end{array}$ & 32.0 & 28.1 & \\
\hline & $\begin{array}{l}1000 \text { to } 1499 \\
\text { euros }\end{array}$ & 173 & 27.1 & \\
\hline & $\begin{array}{l}100 \text { to } 1999 \\
\text { euros }\end{array}$ & 21.3 & 10.5 & \\
\hline & $\geq 2000$ euros & 6.6 & 12.1 & \\
\hline & Missing & 1.3 & 1.3 & \\
\hline \multirow{5}{*}{$\begin{array}{l}\text { House- } \\
\text { hold size }\end{array}$} & 1 person & 14.7 & 10.8 & \multirow{5}{*}{0.274} \\
\hline & 2 people & 14.7 & 20.3 & \\
\hline & 3 people & 16.0 & 21.6 & \\
\hline & 4 people & 46.7 & 36.3 & \\
\hline & $\geq 5$ people & 8.0 & 11.0 & \\
\hline \multirow{3}{*}{$\begin{array}{l}\text { Resi- } \\
\text { dence }\end{array}$} & Rural & 46.7 & 43.4 & \multirow{3}{*}{0.621} \\
\hline & Urban & 53.3 & 56.1 & \\
\hline & Missing & 0.0 & 0.5 & \\
\hline
\end{tabular}

* There are statistically significant differences at the $1 \%$ significance level.

** There are statistically significant differences at the $5 \%$ significance level. household income between 1000 and 1499 euros. Conversely, for non-consumers of honey, this proportion is statistically higher in the income class between 1500 and 1999 euros. Similar results were obtained in a study conducted in China, which discovered that consumers of organic products are prone to have a higher income level [42]. The result of the Mann-Whitney test for comparing the attribute age has shown that the median of the age of honey consumers (31 years) and non-consumers (32 years) are statistically equal ( $p$-value $=0.961)$. Furthermore, the majority of honey consumers prefer to consume local Portuguese honey (85.4\%) in autumn and winter seasons (57.4\%), once a week $(29.3 \%)$ or once a month $(25.8 \%)$ combined with other foods (37.8\%), or use it as a medicine when they are ill (35.0 \%) (Figure 2).

Also in Romania, consumers prefer domestic honey $(83.0 \%)$, purchasing it directly from the producer $(69.0 \%)$ and consuming throughout the year [41]. Similarly, a study reveals that honey appears to be a very common food component in Romanians' diet [48]. In fact, they consume honey at least once a week (33.3 \%) or once a month $(42.7 \%)$. Conversely, in a study conducted in Hungary, only $9.3 \%$ of consumers buy honey on a weekly basis, while $25.3 \%$ do so monthly [28]. Another study showed that Polish consume honey mainly because it positively affects their health [49]. They use it essentially in sandwiches and as a sweetener, several times a month ( $40.0 \%$ ) or less than once a month (25.0\%). Regarding their preferences for national honey, Portuguese consumers mostly mentioned such factors as honey's quality, its contribution to the development of regional economy, reliability and proximity [1].

Consumers are stimulated by the four variables of marketing-mix [45], namely product, price, promotion and place. Price is one of the most visible marketing-mix variables for consumer. Price demonstrates the amount of money customers have to pay to get a particular product [45]. Products, associated with high quality, come in a premium price $[45,46]$. In other words, the consumer is increasingly willing to pay for the variety, 


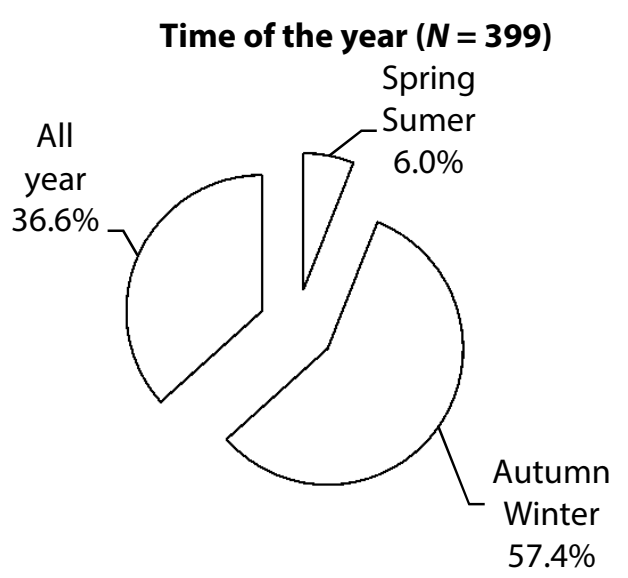

Geographical origin $(N=397)$

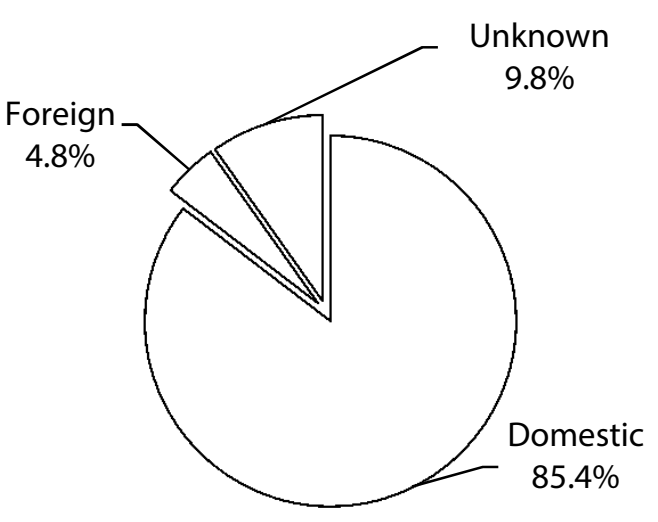

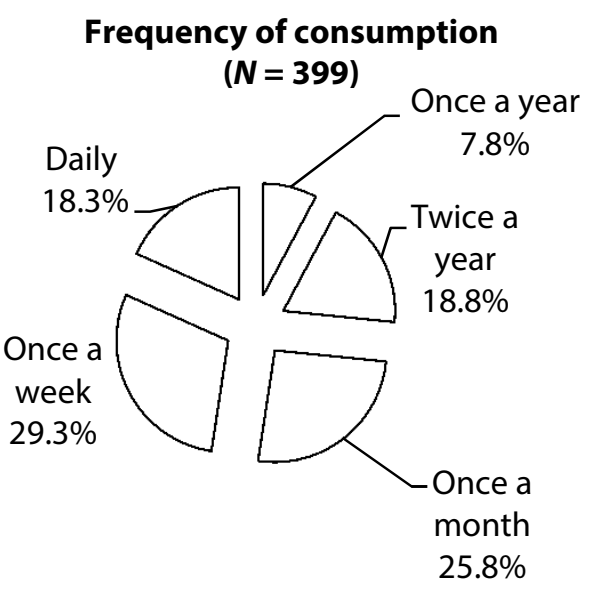

Ways of use $(N=396)$

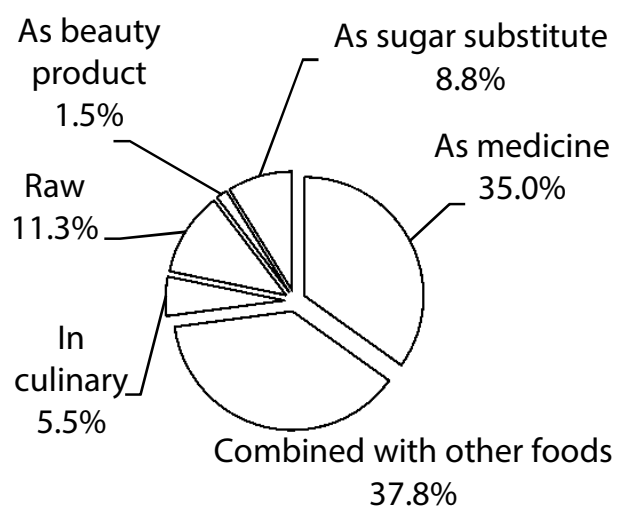

Fig. 2. Habits of honey consumption

innovation and quality of food products. However, some researchers consider that a high price may act as a barrier to increasing the market share of these products [42]. The use of customer-friendly prices may also be a way to attract the consumers' attention [43]. When questioned about the fairness of the price paid for a kilogram of honey, the majority of consumers $(66.6 \%)$ stated that honey is neither expensive nor cheap (Figure 3). This percentage dropped in comparison with the findings $(76.5 \%)$ of an earlier study carried out in Portugal in the same region [1]. Moreover, respondents were asked about their perception on what would be a fair price for honey. The results have shown that surveyed individuals $(\mathrm{N}=395)$ consider an average price of 3.9 euros per $\mathrm{kg}( \pm$ $1.54)$ as a fair price for honey. In the earlier study mentioned above, in the same region, the perception of fair price ranged between 2.5 and $7.5 \mathrm{eu}-$ ros per $\mathrm{kg}$, with an average of 3.53 euros per $\mathrm{kg}$ [1]. There was a $10.5 \%$ increase in the price considered fair by consumers, corresponding to an average annual rate of $1.5 \%$. Given that the average inflation rate for the period was about $1.1 \%$, this trend reflects a real increase in honey price valorisation [44]. Comparing the price, honey consum- ers consider fair given that they were honey producers (Mann-Whitney test), there were statistically significant differences ( $p$-value $=0.000)$. The honey producers $(n=41)$ stated that the fair price would be 4 Euros per kg, on average. Honey consumers $(n=375)$ value honey less, considering that, on average, 3.75 euros per $\mathrm{kg}$ would be a fair price. The comparison with former research on Portuguese market [1] shows a significant decrease in that gap. In the earlier study, the price considered fair by consumer producers and non-producers differed in around 1 euro per kg: 4.4 euros per $\mathrm{kg}$ for producers, and 3.4 euros per $\mathrm{kg}$ for non-producers, on average [1].

Advertising as a part of the promotion strategy is an important component of marketing-mix. It can be a way of influencing the target market by demonstrating the attributes and advantages associated with the use of the product or service. Advertising can be related to either a brand or a product [45]. When questioned on the topic of honey advertising, the majority of consumers (52.9\%) answered negatively (they have never seen honey advertisements). This may be because specialized advertising is dominated by ads for high-calorie and low-nutrient foods, where the 


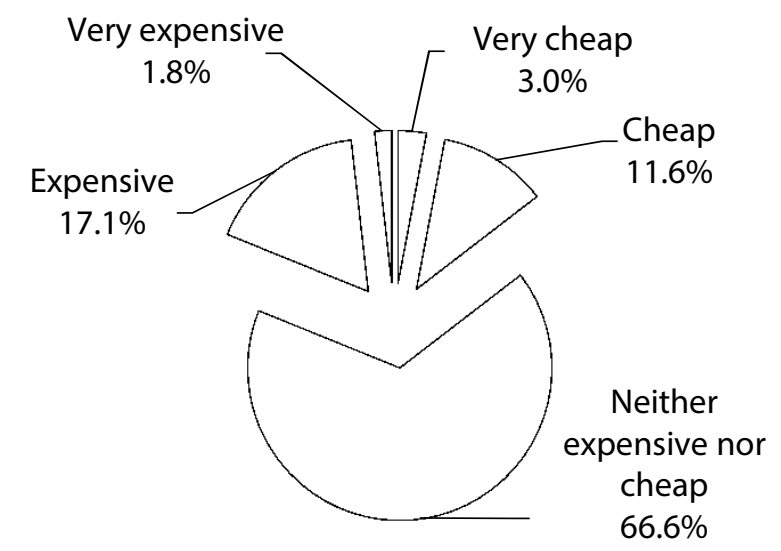

Fig. 3. Perceptions regarding honey price $(N=398)$

disseminated message has a major impact on consumers' preferences [47]. It should be noted, that, in a study conducted in Portugal, $40.6 \%$ of respondents have never seen honey advertising [1]. Given that more and more consumers do not have access to information regarding honey's characteristics and its health benefits, it is necessary to promote communication campaigns that can enlighten consumers and boost honey consumption [1].

Figure 4 shows the factors that consumers value in honey at the moment of purchase. Taste stands out with $71.4 \%$, followed by aroma and appearance (crystalline) with $57.1 \%$, and colour (light or dark) with $51.5 \%$. While the least important factors are density (liquid or thick) with $47.2 \%$, geographical origin and the certification label with about $42.3 \%$ and, finally, price with $41.5 \%$. Consumers greatly value the geographic origin of production, especially when the media disseminate news reporting the adulteration of honey produced abroad [33]. Similarly, taste was also the most valued factor in the studies conducted in Poland [49], Hungary and Romania [25] and Bragança, Portugal [1].
In agro-food production, the product's appearance creates the consumer's first impression of the food. Attributes such as colour, shape or size may also appeal to the consumption of the product. Without an attractive appearance, an agrofood product can be rejected at first sight, even before it is tasted [45]. In this study, consumers preferred amber-coloured honey (balanced, neither light nor dark) (37.4 \%) or light honey (36.7 \%), as can be seen in Figure 5.

Packaging is a key feature of the tangible product. Packaging has to be designed in a way that enables the product's preservation, transportation and storage in good conditions [45]. Packages and labels also serve to demonstrate the product's characteristics, ways of transportation, recycling, or disposing (of both package and product), the expiration date, etc. Packaging may also function as a differentiating factor, given that it is, indeed, an integral part of the product. In addition, food products often require marketing and technical approaches applied to the marketing of other products and services [27]. Convenience, functionality and indulgence are the main trends driving the growth of packaged food market [27]. In this study, honey consumers preferred the higher capacity, $0.5 \mathrm{~kg}(35.1 \%)$ and $1 \mathrm{~kg}(35.4 \%)$, glass (86.1\%) containers, duly labelled, as labelling broadens perceived reliability (70.8\%). As can be seen in Figure 5, the preferred type of container is the glass jar (54.1\%). When comparing these results with the earlier study conducted in the same city [1], it was verified that consumers' buying habits were unchanged. Similar results for packaging attributes were obtained in Ireland. However, Irish consumers preferred darker honey [26].

Figure 6 shows that honey consumers favour short supply chains. In fact, $44.5 \%$ of honey consumers often buy honey directly from the producer. This percentage was even higher (51.7 \%) in

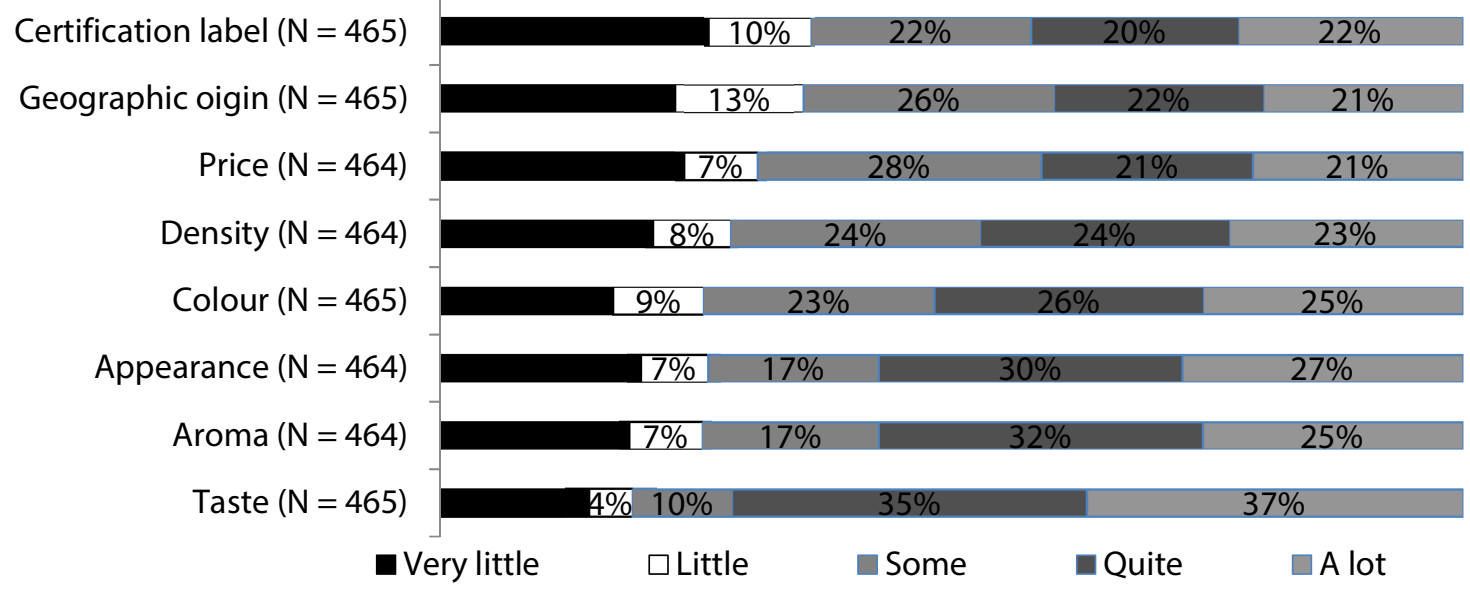

Fig. 4. Attributes valued in honey 
Colour $(\mathbf{N}=398)$

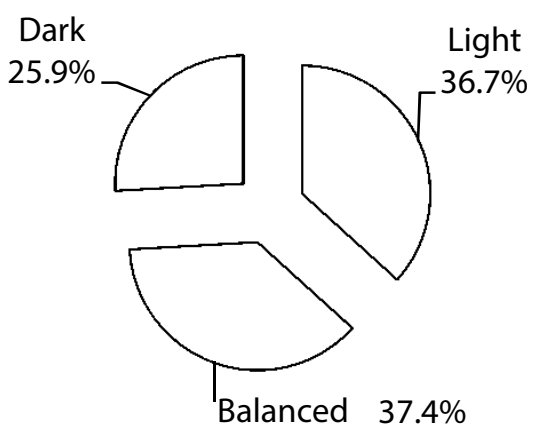

Packaging material $(\mathrm{N}=\mathbf{3 8 2})$

Glass and plastic

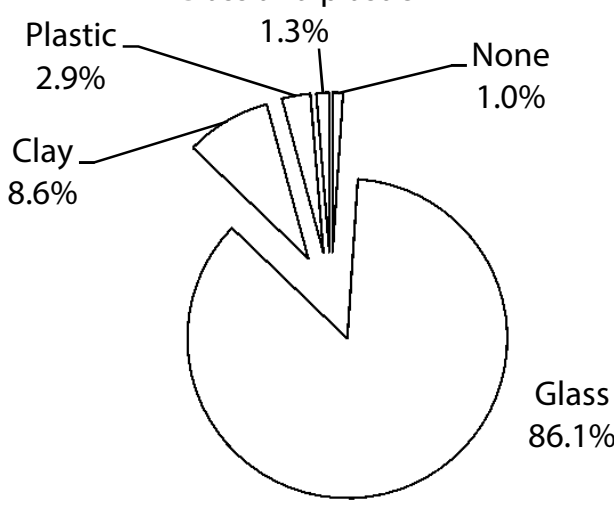

Packaging capacity $(\mathrm{N}=396)$

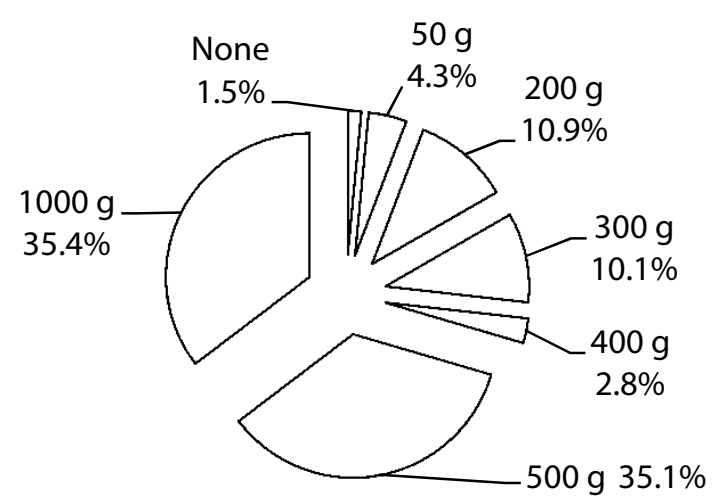

Label $(\mathrm{N}=396)$

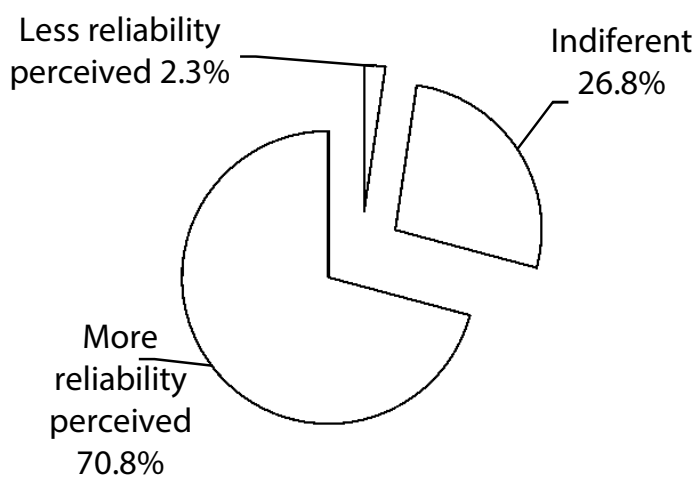

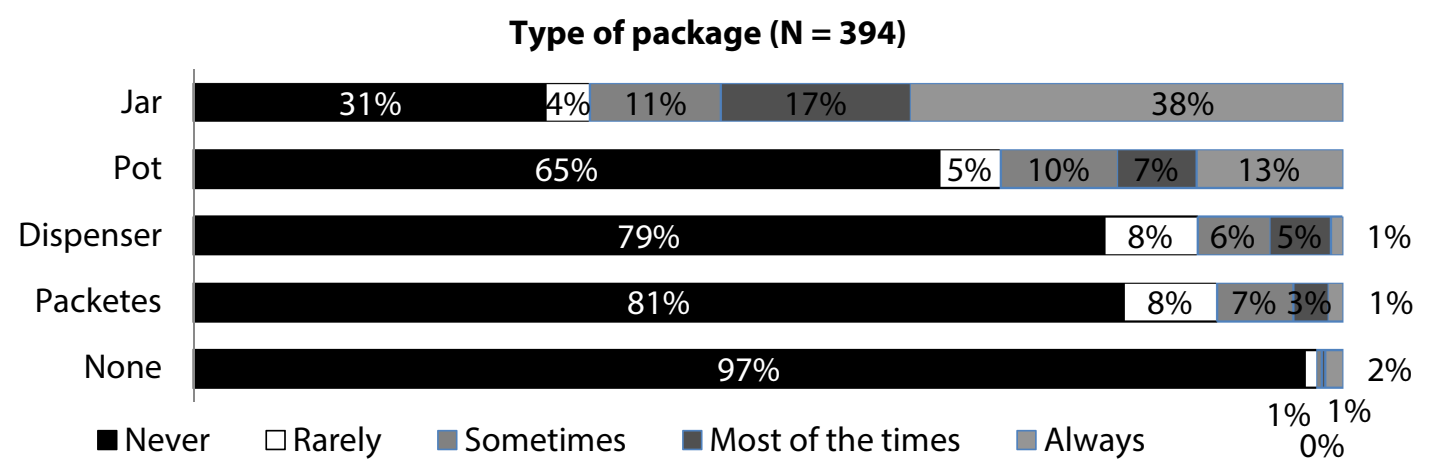

Fig. 5. Consumers' preferences while choosing honey products

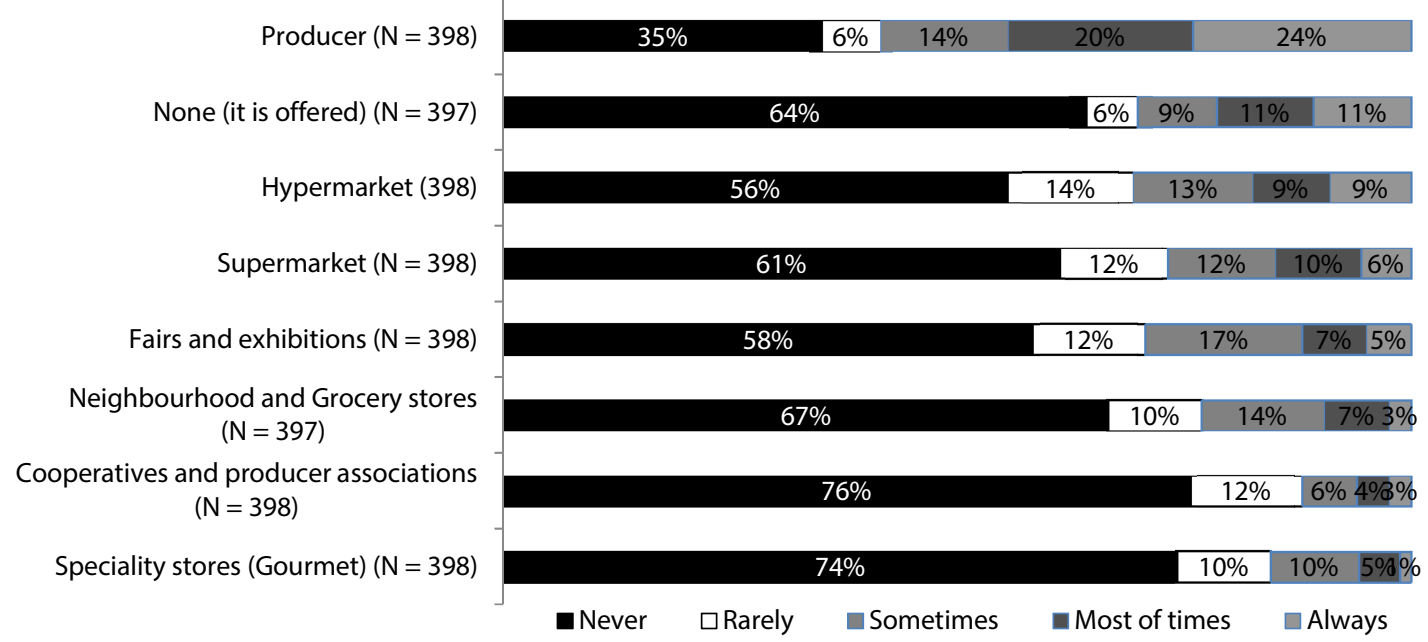

Fig. 6. Place of purchasing honey 


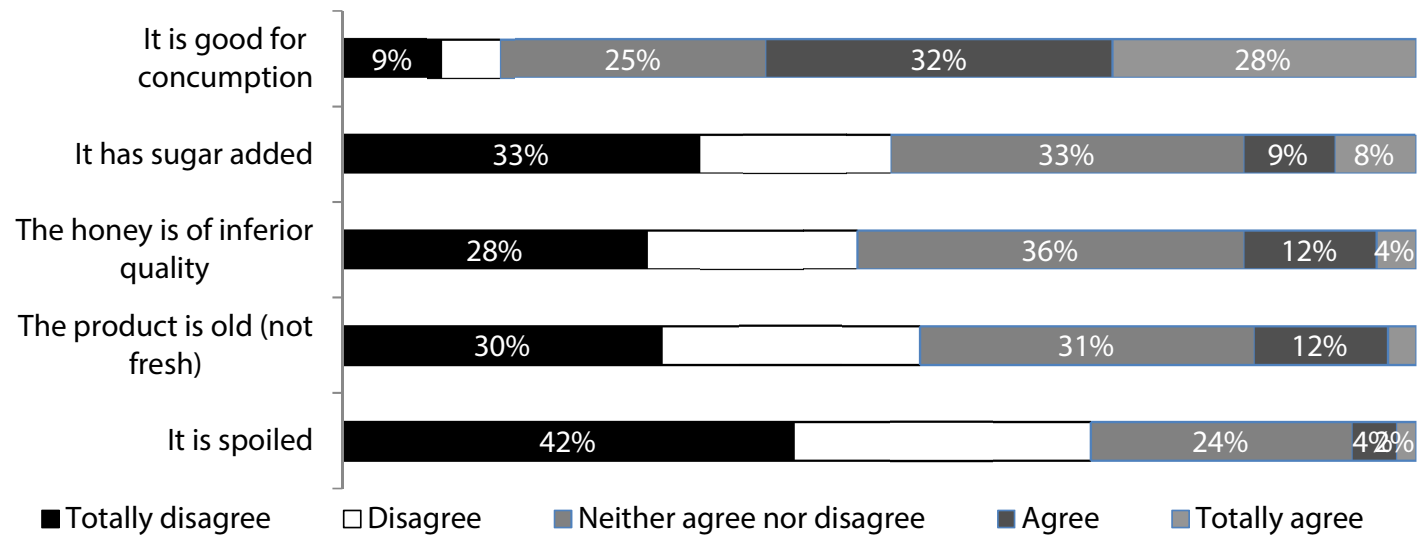

Fig. 7. Beliefs of consumers regarding crystalized honey

a study conducted in Portugal [1]. Similar results were obtained in a study conducted in Poland [49], in which outdoor markets (32.0\%) and apiaries (27.4\%) were the most frequently visited places for purchasing honey. The information and communication technologies (especially the Internet) can complement other marketing channels [50]. Its role in the information management and in strengthening the relationship with consumers can be even more significant than online sales [50]. Internet can be an important sales channel for producers who produce goods with specific attributes, products with high value added and products with more elaborated packaging potentially used as gifts [50]. In fact, the gourmet market offers the small agro-industries the opportunity to operate in a market niche with great growth potential satisfying the consumers' demand for high-quality artisanal food [26]. Consumers associate the gourmet concept with the high-quality products with unique characteristics, produced locally in small quantities that are usually certified [5, 51].

Crystallized honey is a good indicator of quality and purity. However, by lack of knowledge, consumers often misjudge it. Figure 7 shows the honey consumers' opinion regarding crystallized honey. As can be seen, $60.5 \%$ of the consumers consider that this honey is good for consumption (60.5\%). The majority of consumers (69.7\%) consider that crystallized honey is not spoiled, or old (53.7\%), is not of inferior quality (48.0\%), and that it does not have added sugar (51.1\%). These results show that the consumers of Bragança are, in general, knowledgeable about the product. Despite this, the high percentage of respondents (about $30 \%$ ) do not have opinion (neither agree nor disagree) regarding crystallized honey. It means that there is a necessity for communication campaigns to inform consumers and boost honey consumption, as mentioned earlier [1].

The output of the logistic regression indicates that the assessed model is statistically significant
Table 3

Binary Logistic Regression Model

\begin{tabular}{|c|c|c|c|}
\hline \multicolumn{4}{|c|}{$\begin{array}{l}\text { Dependent variable: Honey consumption } \\
Y=0 \text { (Yes); } Y=1 \text { (No) }\end{array}$} \\
\hline Variables & $\beta$ & $\begin{array}{l}\text { Standard } \\
\text { Deviation }\end{array}$ & $p$-value \\
\hline Constant & 1.719 & 0.277 & $0.000^{*}$ \\
\hline Taste & -4.287 & 0.629 & $0.000^{* *}$ \\
\hline Colour & -2.974 & 0.871 & $0.001^{*}$ \\
\hline Certification label & 3.988 & 1.018 & $0.000^{*}$ \\
\hline Geographic origin & -2.116 & 0.727 & $0.004^{*}$ \\
\hline \multicolumn{4}{|c|}{$\begin{array}{l}\text { Likelihood Log }=262.948 ; p \text {-value }=0.000 \\
\text { Nagelkerke's } R^{2}=0.689\end{array}$} \\
\hline
\end{tabular}

* Significant parameter at $1 \%$ significance level.

$(p$-value $=0.000)$, as can be seen in Table 3 . The test of the model's global validity shows that its explanatory power is greater than the power of the model containing only the independent term (Table 3).

The test of the individual parameters' significance shows that the parameters of taste, colour, geographic origin and certification label are statistically significant for a level of significance of $1 \%$. These attributes account for $68.9 \%$ of the consumer's decision to purchase honey.

Certification label is significant for non-consumers of honey. Probably non-consumers value this attribute when purchasing honey to offer to someone, given that certification label often works as indicator of superior quality. Contrary, the parameters of taste, colour and the geographic origin are important attributes valued by honey consumers in the decision-making process while purchasing the product.

\section{Conclusion}

The objective of this study was to outline the profile of honey consumers, describe their purchasing and consumption habits and identify determining factors for its consumption in Bragança, 
a city in northeast of Portugal. The majority of honey consumers is aged between 25 and 64 years, female, employed, has a higher education degree, lives in an urban setting, in households of 3 or 4 people with a monthly income up to $999 \mathrm{eu}-$ ros. Honey consumer profile is statistically different from the profile of non-consumer. We found differences regarding the professional status and the monthly income of the household. The professionally active individuals are the ones consuming more honey; the unemployed people are consuming the smallest amount. Regarding monthly income of the household, we discovered that the respondents who consume more honey earn more money (income between 1000 and 1499 euros), while people consuming less honey have the incomes between 1500 and 1999 euros.

As for the consumption habits, it was possible to verify that the majority of honey consumers prefer to consume honey of national origin, once a week or once a month, usually in autumn and winter seasons, mixed together with other foods or used as a medicine. The preference for domestic honey is based on the factors, such as quality, contribution to the development of the regional economy, reliability and proximity of producers (origin). In fact, honey is often purchased directly from the producer. Honey is a product that, in the opinion of most consumers, is not a superfluous good. It is neither expensive nor cheap with its fair price being, on average, $€ 3.9$ per $\mathrm{kg}$. Honey consumers prefer honey packaged in properly labelled and high capacity glass jars ( 0.5 and $1 \mathrm{~kg}$ ).

While choosing the product, consumers recognize honey's authenticity and innate properties. In fact, certification label, taste, colour and geographic origin have proved to be the determining attributes in the decision-making process of purchasing honey.

On the one hand, the cross-sectional nature of the study is a limitation of the research that can be overcome in future investigations that allow following the evolution of the buying and consumption habits for this type of product. On the other hand, given that it is a non-probabilistic, accidental sample, the results are valid only for the particular group of studied consumers and cannot be extrapolated to the population. To fill this gap, we are planning to base the future studies on representative probabilistic samples.

\section{Acknowledgments}

The article has been prepared with the support of (a) the Foundation for Science and Technology (FCT, Portugal) and the ERDF under the program PT2020 for financial support to CIMO (UID/AGR/00690/2019) and (b) CETRAD, funded UI \& D by national funds through the Foundation for Science and Technology (FCT), under the project UID/SOC/04011/2019.

\section{References}

1. Ribeiro, M., Matos, A., Almeida, A., Fonseca, A., Fernandes, B., Mota, C., Gonçalves, E., Garcia, E., Pereira, E., Garção, H., Guedes, H., Rodrigues, M., Neto, M. \& Abreu, R. (2009). Produtos Alimentares Tradicionais: Hábitos de compra e consumo do mel [Traditional alimentary products: purchase habits and honey consumption]. Revista de Ciências Agrárias [Journal of Agrarian Sciences], 32(2), 97-112. (In Port.)

2. Pocol, C. B. \& Teselios, C. M. (2012). Socio-economic determinants of honey consumption in Romania. Journal of Food, Agriculture \& Environment, 10(2), 18-21.

3. Mazol, I., Sroka, Z., Sowa, A., Ostrowska, A., Dryś, A. \& Gamian, A. (2016). Antiradical and antimicrobial activity of phenolic fractions obtained from honeys. Acta poloniae pharmaceutica, 73(2), 379-388.

4. Oryan, A., Alemzadeh, E. \& Moshiri, A. (2016). Biological properties and therapeutic activities of honey in wound healing: A narrative review and meta-analysis. Journak of Tissue Viability, 25(2), 98-118.

5. Ribeiro, M. \& Fernandes, A. (2015). Perceção, conhecimento e hábitos de compra de produtos gourmet de marca branca: $\mathrm{O}$ caso de Bragança, Portugal [Perception, knowledge and buying habits of gourmet products: The case of Bragança, Portugal]. In: XVII Jornadas Luso-Espanholas de Economia Empresa [The XXVIII Portuguese-Hispanic Conference on Company's Economy]. Universidade da Beira Interior, Covilhã, Portugal. (In Port.)

6. Zamberlan, L. \& Santos, D. (2010). O comportamento do consumidor de mel: um estudo exploratório [Honey consumer's behavior: an exploratory study]. RACI, 5(10), 1-21. (In Port.)

7. Mogib, E., Faeza, A. \& Yahia, S. (2011). Cytoprotective Effect of Honey Against Chromosomal Breakage in Fanconi Anemia Patients in vitro. Indian Journal of Human Genetics, 17(2), 77-81.

8. Pipicelli, G. \& Tatti, P. (2009). Therapeutic properties of honey. Health, 1(2), 281-283.

9. Ahmed, S. \& Othman, N. (2013). Review of the medicinal effects of tualang honey and a comparison with manuka honey. Malaysian Journal of Medical Sciences, 20(3), 6-13.

10. Chen, C., Campbell, L., Blair, S. \& Carter, D. (2012). The effect of standard heat and filtration processing procedures on antimicrobial activity and hydrogen peroxide levels in honey. Frontiers in Microbiology, 3, 1-8.

11. Kuncic, M. K., Jaklic, D., Lapanje, A. \& Gunde-Cimerman, N. (2012). Antibacterial and antimycotic activities of Slovenian honeys. British journal of biomedical science, 69(4), 154-158. 
12. Al-Waili, N., Salom, K. \& Al-Gamdi, A. (2011). Honey for Wound Healing, Ulcers, and Burns; Data Supporting Its Use in Clinical Practice. The Scientific World Journal, 11, 766-787.

13. Cook, J., Dryden, M., Patton, T., Brennan, J. \& Barrett, J. (2015). The antimicrobial activity of prototype modified honeys that generate reactive oxygen species (ROS) hydrogen peroxide. BMC Research Notes, 28, 8-20.

14. Pereira, C., Barreira, J., Calhelha, R., Lopes, M., Queiroz, M., Vilas-Boas. M., Barros. L. \& Ferreira. I. (2015). Is honey able to potentiate the antioxidant and cytotoxic properties of medicinal plants consumed as infusions for hepatoprotective effects? Food Funct, 6(5), 1435-1442.

15. Oryan, A., Alemzadeh, E. \& Moshiri, A. (2016). Biological properties and therapeutic activities of honey in wound healing: A narrative review and meta-analysis. Journal of Tissue Viability, 25(2), 98-118.

16. Zamora, L., Beukelman, C., van den Berg, A., Aerts, P., Quarles van Ufford, H., Nijland, R. \& Arias, M. (2017). An insight into the antibiofilm properties of Costa Rican stingless bee honeys. Journal of Wound Care, 26(4), 168-177.

17. Yaghoobi, R., Kazerouni, A \& Kazeuroni, O. (2013). Evidence for clinic use of honey in wound healing as an anti-bacterial. Anti-inflammatory, anti-oxidant and anti-viral agent: a review. Jundishapur Journal of Natural Pharmaceutical Products, 8(3), 100-104.

18. Jamróz, M., Paradowska, K., Zawada, K., Makarova, K., Kaźmierski, S. \& Wawer, I. (2014). ${ }^{1} \mathrm{H}$ and ${ }^{13} \mathrm{C}$ NMR-based sugar profiling with chemometric analysis and antioxidant activity of herbhoneys and honeys. Journal of the Science of Food and Agriculture, 94(2), 246-55.

19. Alvarez-Suarez, J., Gasparrini, M., Forbes-Hernández, T., Mazzoni, L. \& Giampieri, F. (2014). The Composition and Biological Activity of Honey: A Focus on Manuka Honey. Foods, 3(3), 420-432.

20. Cauich Kumul, R., Ruiz Ruiz, J., Ortíz Vázquez, E. \& Segura Campos, M. (2015). Antioxidant potential of melipona beecheii honey and its relationship to health: a review. Nutricion hospitalaria, 32(4), 1432-1442.

21. Bardy, J., Slevin, N., Mais, K. \& Molassiotis A. (2008). A systematic review of honey uses and its potential value within oncology care. Journal of Clinical Nursing, 17(19), 2604-2623.

22. Henatsch, D., Wesseling, F., Kross, K. \& Stokroos, R. (2016). Honey and beehive products in otorhinolaryngology: a narrative review. Clinical Otolaryngology, 41(5), 519-31.

23. Ediriweera, E. \& Premarathna, N. (2012). Medicinal and cosmetic uses of Bee's Honey - A review. Ayu, 33(2), $178-82$.

24. Wardle, J., Lui, C. W. \& Adams, J. (2012). Complementary and alternative medicine in rural communities: current research and future directions. Journal of Rural Health, 28(10), 1-112.

25. Pocol, C. \& Ványi, G. A. (2012). A Comparison between Hungarian and Romanian Honey Consumption. Bulletin of the University of Agricultural Sciences \& Veterinary Medicine Cluj-Napoca. Horticulture, 69(2), 244-252.

26. Murphy, M., Cowan, C., Henchion, M. \& O’Reilly, S. (2000). Irish consumer preferences for honey: a conjoint approach. British Food Journal, 102(8), 585-598.

27. Ahmed, A., Ahmed, N. \& Salman, A. (2005). Critical issues in packaged food business. British Food Journal, 107(10), $760-780$.

28. Ványi, G. A., Csapó, Z. \& Kárpáti, L. (2011). Evaluation of consumers’ honey purchase habits in Hungary. Journal of Food Products Marketing, 17, 227-240.

29. Ribeiro, M.; Fernandes, A. \& Cabo, P. (2018). Características físicas e organoléticas promotoras do consumo do mel. Revista Portuguesa de Zootecnia, 3 (1), 277-283.

30. Yeow, S. H. C., Chin, S. T. S., Yeow, J. A. \& Tan, K. S. (2013). Consumer Purchase Intentions and Honey Related Products. Journal of Marketing Research \& Case Studies, 1-15.

31. Ismaiel, S., Al-Kahtani, S., Adgaba, N., Al-Ghamdi, A. \& Zulail, A. (2014). Factors That Affect Consumption Patterns and Market Demands for Honey in the Kingdom of Saudi Arabia. Food and Nutrition Sciences, 5(17), $1725-1737$.

32. Zulail, A., Ismaiel, S., Al-Kahtani, S., Al-Ghamdi, A. A., \& Adgaba, N. (2014). Qualitative Factors Affecting the Price and Demand of Honey in Saudi Arabia. Australian Journal of Basic and Applied Sciences, 8(10), 199-206.

33. Wu, S., Fooks, J., Messer, K. \& Deleney, D. (2015). Consumer demand for local honey. Applied Economics, 47(41), 4377-4394.

34. EUROSTAT. (2017). Market Information-Honey and sweeteners. Retrieved from: https://www.cbi.eu/market-information/honey-sweeteners/trade-statistics/ (Date of access: 01.05.2017).

35. FAOSTAT. (2017). Food and Agricultural data. Retrieved from: https://www. fao.org/faostat/en/\#home/ (Date of access: 01.05.2017).

36. FNAP (Federação nacional dos Apicultores de Portugal). (Set/2016). Plano de ação pela transparência do mel [FNAP (National Federation of Beekeepers of Portugal). (Sep/2016). Honey Transparency Action Plan]. (2016). APINFO, 1, 1-16. (In Port.)

37. Jung, C. (2004). Metodologia para pesquisa e desenvolvimento [Research and Development Methodology]. Rio de Janeiro: Editora Axcel Books do Brasil. (In Port.)

38. INE. (2012). Censos 2011. Lisboa: Instituto Nacional de Estatística. (In Port.)

39. Maroco, J. (2007). Análise Estatística com utilização do SPSS [Statistical Analysis using SPSS]. Lisboa: Edições Sílabo, 824. (In Port.)

40. Pestana, M. \& Gageiro, J. (2014). Análise de Dados para Ciências Sociais: A complementaridade do SPSS [Data analysis for social sciences: the complementarity of SPSS]. Lisboa: Edições Sílabo, 1240. (In Port.) 
41. Pocol, C. \& Bolboacă, S. (2013). Perceptions and trends related to the consumption of honey: A case study of NorthWest Romania. International Journal of Consumer Studies, 37(6), 642-649.

42. Xie, B., Wang, L., Yang, H., Wang, Y. \& Zhang, M. (2015). Consumer perceptions and attitudes of organic food products in Eastern China. British Food Journal, 117(3), 1105-1121.

43. Spohr, J. \& Espartel, L. (2009). A influência da construção de preços atrativos no processo de decisão de compra do consumidor [The influence of attractive pricing construction on consumer's decision-making process]. In: $X$ salão de iniciação científica, Faculdade de Administração, Contabilidade e Economia [X scientific initiation hall, School of Business, Accounting and Economics]. Porto Alegre, Brasil. (In Port.)

44. INE/Pordata (2017). Índice de Preços ao Consumidor [Consumer Price Index]. Retrieved from: https://www.pordata. pt (Date of access: 05.05.2017). (In Port.)

45. Barroso, M. \& Madureira, T. (2005). Marketing nas Pequenas e Médias Explorações Agrícolas [Marketing in Small and Medium Farms]. Porto: Sociedade Portuguesa de Inovação. (In Port.)

46. Mello, L. \& Marreiros, C. (2009). Marketing de Produtos Agrícolas [Marketing of Agricultural Products]. Lisboa: Associação dos Jovens Agricultores de Portugal. (In Port.)

47. Radnitz, C., Byrne, S., Goldman, R., Sparks, M., Gantshar, M. \& Tun, K. (2009). Food cues in children's television programs. Appetite, 52(1), 230-233.

48. Arvanitoyannis, I. \& Krystallis, A. (2006). An empirical examination of the determinants of honey consumption in Romania. International Journal of Food Science and Technology, 41(10), 1164-1176.

49. Kowalczuk, I., Jeżewska-Zychowicz, M. \& Trafiałek, J. (2017). Conditions of honey consumption in selected regions of Poland. Acta Scientiarum Polonorum. Technologia Alimentaria, 16(1), 101-112.

50. Canavan, O., Henchion, M. \& O'Reilly, A. (2007). The use of the internet as a marketing channel for Irish speciality food. International Journal of Retail \& Distribution Management, 35(2), 178-195.

51. Dreyer, H., Strandhagen, J., Hvolby, H., Romsdal, A. \& Alfnes, E. (2016). Supply chain strategies for speciality foods: a Norwegian case study. Production Planning \& Control, 27(11), 878-893.

\section{Authors}

Maria Isabel Barreiro Ribeiro - PhD, Associate Professor, Bragança Polytechnic Institute; Mountain Research Centre; Scopus Author ID: 56001466000 (Campus de Santa Apolónia, Bragança, 5300-253; e-mail: xilote@ipb.pt).

António José Gonçalves Fernandes - PhD, Associate Professor, Bragança Polytechnic Institute; Mountain Research Centre; Scopus Author ID: 55815966700 (Campus de Santa Apolónia, Bragança, 5300-253; Vila Real, 5001-801, Portugal; e-mail: toze@ipb.pt).

Paula Sofia Alves do Cabo - PhD, Associate Professor, Bragança Polytechnic Institute; Mountain Research Centre; Scopus Author ID: 41961021900 (Campus de Santa Apolónia, Bragança, 5300-253, Portugal; e-mail: toze@ipb.pt).

Francisco José Lopes de Sousa Diniz - PhD, Associate Professor with Habilitation, University of Trás-os-Montes e Alto Douro; Centre for Transdisciplinary Development Studies; Scopus Author ID: 55881300300 (Polo II da ECHS, Quinta de Prados, Vila Real, 5000-801, Portugal; e-mail: fdiniz@utad.pt). 